Nataliia Maliutina

Uniwersytet w Białymstoku

Wydział Filologiczny

Kolegium Literaturoznawstwa

tel.: +48539173824

e-mail: malutina2002@ukr.net

ORCID ID: https://orcid.org/0000-0002-5787-2753

\title{
Локус молодежной тусовки в современной русскоязычной драме
}

Ключевые слова: тусовка, самоидентификация, стиль жизни, пространство, место

Явление „молодежной тусовки”, функционирующее в современной массовой культуре в различных значениях (круга лич, объединенньих общими интересами, стиля жизни, способа времяпрепровождения, места и пространства проведения мероприятия, а также соииальной структуры (неформального) объединения в рамках молодежных субкультур) и т.n., [Лурье, Кулева] не случайно стало объектом внимания новейшей русскоязычной драмы за последние 20 лет. Это можно связать с переформатированием молодежной культуры как социально-культурного института в контексте глобальных изменений городского пространства, с одной стороны, а также с обостренным вниманием к процессам личностной (само)идентификации, с другой. Так, в ряде культурологических исследований подчеркивается предельно персонализированный характер тусовочного общения, поскольку культ индивидуальности содержит огромный творческий потенциал, позволяющий создавать иную новую реальность в тех или иных формах (формате) общения [Мизиано 2002, 353] ${ }^{1}$.

1 В работе Виктора Мизиано „Тусовка” как социокультурный феномен это явление определяется как предельно персонализированная форма самоорганизации межличностных отношений. См.: В. Мизиано, „Тусовка” как соииокультурный феномен, [в] Художественная культура ХХ века. Сборник статей, Москва 2002, с. 353. 
Локализированный характер тусовки позволяет сместить фокус исследовательского внимания в сферу моделирования в поэтике текста пьесы некого символического пространства общения, переживания, идентификации, самоорганизации персонажей, равно как и концептуализации некого социально-культурного феномена. Обращаясь к новейшей русской драме, посвященной проблемам молодежной тусовки, постараюсь выяснить, как место ее проведения определяет характер взаимодействия героев, обуславливает процессы личностной самоидентификации и картину мира в пьесе.

В своем исследовании я опираюсь на достаточно разработанные в современном драмоведении представления о том, что категория пространства (реального или воображаемого, внешнего или внутреннего, ментального или театрального...) в поэтике современной драматургии во многом связана с глобальной субъективизацией и виртуализацией картины мира в высказыванииㄹ․

Кризис репрезентации, по мнению многих исследователей, обусловил заметное преобладание во многих пьесах метатеатрального формата пространства, в котором вниманию читателя предстают черты символизации, виртуализации, наполнения пространства экзистенциальным содержанием. Анна Краевская проанализировала широкий спектр процессов перформатизации высказывания в современной драме, которые, безусловно, охватывают и категорию сценического/драматургического пространства [Krajewska 2009]. Обосновывая категорию внутреннего пространства, ученые наделили его свойствами: инструмента самопознания, идентификации героя, его самовыражения (часто иллюзорного) ${ }^{3}$. Способность драматургического пространства служить средством моделирования (само)идентичности героя связывается с интертекстуальными, метатеатральными процессами трансгрессии рецепции зрителя.

Принимая за основу анализа эти и другие наблюдения, считаю возможным рассмотреть, как в современной русскоязычной драме представлены формы(способы) локализации молодежной тусовки и как

2 Эта проблема достаточно подробно исследована в работах Матэуша Боровски (в книге: Elementy dramatu. Analizy diagnostyczne, Kraków 2009), Анны Краевской, Эвы Вонхоцкой, Беаты Попчик-Щенсной и др. (в книге Przestrzenie we wspólczesnym teatrze $i$ dramacie, Kraków 2009), Ольги Журчевой, Натальи Махининой, Лилии Насрутдиновой и др. (в книге Современная российская и европейская драма и театр, Казань 2017). Отметим, что речь идет о работах, посвященных поэтике текста драмы, а не ее театральным воплощениям.

3 Смотри статьи Эвы Вонхоцкой, Матэуша Боровски, Ольги Журчевой в указанных сборниках и др. 
они связаны с местом ее проведения (реальным: квартира, часть дома, или виртуальным). Предполагаю, что специфика представления тусовки может быть обусловлена совпадением( или несовпадением) взгляда героев (зачастую - подростков) и автора процессами (само)идентификации героя.

Вслед за Дэвидом Харви, анализируя локусы городской среды, сферу межличностных отношений героев, их внутренний мир, процессы создания и переживания картины мира, стоит конкретизировать употребление понятий пространства и места. Последнее понимается как географическая локация воздействия определенных социальных и экономических механизмов ${ }^{4}$. При этом понятие пространства зачастую используется в нескольких значениях: прежде всего, пространство как форма коммуникации группы лиц, публичное пространство как социабельность (то есть способность осуществлять соииальное взаимодействие в тех или иньх публичньх местах: клубах, кофейнях, скверах ...) [Лебедева 2016, 108], личное пространство. В соответствии со сферой воспринимаемого пространство рассматривается как совокупность материальных объектов и как совокупность идей и представлений о нем, выраженных в репрезентациях, в основном, дискурсивных [Лефевр 2015].

В новейшей русскоязычной драме последних двадцати лет все отчетливее тематизирована драматургия молодежного общения в культурных пространствах (гендерньх, субкультурных, этнических, интеллектуальной среды, школьных и студенческих групп...). Моделирование культурных пространств в самом расширительном смысле этого явления позволяет ставить и решать (в пьесах современных русскоязычных драматургов) проблему репрезентации структурированного социального опыта, в том числе, опыта времяпрепровождения, освоения пространства, осмысления стиля жизни, процессов идентификации молодежных групп, принадлежащих или нет к молодежным субкультурам, равно как и процессов (само)идентификации.

В процессе анализа ряда пьес русскоязычных авторов разных школ и направлений: Ирины Васьковской и Дарьи Уткиной (Дар моей невинности, Бог ездит на велосипеде), Натальи Блок (Фото топлес), Людмилы Духаниной (Тусовка ранним вечером, Чердак, Скамейка $M-K)$, Юлии Тупикиной (Кулинарныци кружок), Натальи Юровой (Крейзи

\footnotetext{
4 Смотри подробнее о позиции Д. Харви, который ввел в социологию городского пространства понятие „место”, в статье: Е. Лебедева, Трансформачия публичного пространства постсоветских городов, „Социология” 2016, № 4, с. 108.
} 
фэнтези), Игоря Шприца (Мерси), Игоря Витренко (Кого я нашел в соцсети), стало понятно, что действие в них разворачивается в пространстве, репрезентирующем реальное место проживания и коммуникации героев (чаще всего это квартира, часть дома, напр., чердак, но может быть, например, бомбоубежище или скамейка, раздевалка $)^{5}$. Нередко действие происходит в воображаемом пространстве гиперреальности (медиареальности), в ряде пьес тусовка происходит в форме зависания по скайпу и т.п. ${ }^{6}$ Рассматривая подробнее некоторые из этих пьес, отметим, что характер высказывания в них зависит от представления о конкретном адресате. Так, вышеназванные пьесы Л. Духаниной, И. Шприца, Ю. Тупикиной предназначены как для взрослых, так и для подростков. Подобная коммуникативная стратегия проявляет себя на уровне рецептивных кодов, непосредственно представленных в авторских ремарках, в которых автор апеллирует к опыту зрелого человека, и это формирует авторскую картину мира. Так же это отразилось на лексическом уровне, подростковый сленг соседствует с речевыми оборотами, характерными для взрослых. В пьесах же И. Васьковской, Д. Уткиной, Н. Блок, И. Витренко распознаются коммуникативные интенции, адресованные подросткам с их системой ценностей, языковым сленгом и тп.

Анализируя поэтику пьес, предназначенных для подростков, обратим внимание на то, что действие в них зачастую разворачивается в отчужденном от взрослых пространстве, куда герои могут попасть в мечтах, либо в своих воспоминаниях. Как отмечают исследователи, в подобных пьесах о трагической неспособности подростка социализироваться во враждебном ему мире наблюдается идеализация пространства воспоминания, тенденция к его мифологизации [Маханина 2007, 54-55].

Тусовку будем понимать, как место, форму публичности, стиль жизни, характер проведения досуга. В современной русской драме ее можно представить в виде некой модели социума, определяющей картину мира, процессы личностной (само)идентификации и трансформации

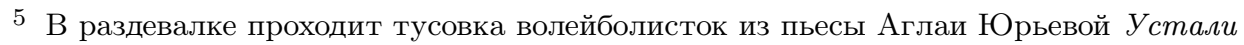
звезды говорить о Боге, и девушки играли в волейбол.

6 Различая эти виды пространств, мы учитываем трехчленную классификацию Анри Лефевра. Речь идет о репрезентации пространства как отношений власти, идеологии; о пространстве репрезентаций как о повседневном опыте проживания, причем пространство может быть как реальным, так и воображаемым. и, наконец, пространство практик (организации труда, досуга). 
героев. Анализируя эту проблему, буду также опираться на наблюдение американского социолога Шарон Зукин о том, что публичное пространство характеризуется возможностью самостоятельно „режиссировать" собственную активность, то есть устанавливать свои „правила игры" [Лебедева 2016, 109]. Такой подход позволяет представить тусовку как некий социокультурный организм с присущими ему правилами, ритуалами, традициями, которые, впрочем, не остаются неизменными, поскольку отражают динамику личностных трансформаций.

Как отмечает ряд культурологов, особую роль в изучении молодежной субкультуры, в том числе и тусовки, играет то, что она определяет ценностные ориентации и нормы поведения, этические и эстетические воззрения участников [Неформальньле.. 2008]. Исследователи предлагают в соответствии с этим и такое понимание феномена неформальной молодежной субкультуры: это система символов, норм, ценностей и социальных институтов, определяющая самоидентификацию, поведение и деятельность индивидов и групп, регулируя, таким образом, значимую часть жизнедеятельности своих адептов [Неформальнье... 2008, 4].

Этот же концепт идентификации определяет, по мнению авторов сборника, явление „тусовки”, под которым понимают: „..cтиль жизни молодежной культуры, оно же, в то же время, обозначает и место встреч. Место в значительной мере определяет и идентичность, становясь символом групповой принадлежности ..." [Неформальные... 2008, 11].

Локус молодежной тусовки представлен в целом ряде современных пьес русскоязычных драматургов (из России, Украины), действие в которых связано с местом и характером проведения досуга молодыми людьми (чаще всего, это учащиеся школы, студенты, бывшие однокурсники, которых объединяет общность интересов, занятий, увлечений). Даже в тех случаях, когда на тусовках (вечеринках) в пьесе собираются люди более зрелого возраста (как, например, в пьесе Виталия Познина День закрытых дверей (2018) и в драме с элементами комедии Аси Котляр Пижамная вечеринка (2017), героиням которой по 45-50 лет, они бывшие однокурсницы и подруги) их стиль общения передает интересы определенной социальной группы людей, напоминающей молодежную тусовку.

Речь пойдет о тех пьесах, в которых представлена не случайная вечеринка однажды встретившихся людей, а ситуация проведения досуга конкретного круга лиц, в процессе которого формируются ценности молодежной группы и/или отдельной личности, осуществляются процессы (само)идентификации героев. 
В перечисленных выше пьесах рассмотрим процессы репрезентации как реального места (пространства), так и внутреннего воображаемого пространства или гиперпространства (медиапространства), создающихся интерактивно, в процессе перцепции реципиента.

Действие пьес Л. Духаниной, Ю. Тупикиной, И. Васьковской и Д. Уткиной (Дар моей невинности) происходит в обычной городской квартире. Это пространство оказывается способным вместить довольно большое число разных, часто не очень близких друг другу людей. Не случайно квартира становится местом, в котором в силу накопления эмоционального напряжения разворачиваются драматические коллизии, осознается истинное положение вещей, а герои переживают процессы взросления или личностного изменения. Тусовочное пространство современной квартиры зачастую приобретает смежные функциональные характеристики. Так, например, в пьесе Юлии Тупикиной $K y$ линарный кружок (2013) действие происходит в кухне-студии, то есть в гостиной, совмещенной с кухней. Место действия определяет и сюжет пьесы: успешный тренер Миша создал клуб, по его словам, „...для обмена энергией. Для совместного погружения в кулинарию, в искусство кулинарии. Мы все улучшим наши способности, овладеем новыми навыками. в результате произойдет апдейт. Мы сделаем скачок и...” [Тупикина]. Как отмечено в аннотации к пьесе: „По мнению Миши кружок должен стать легкой и приятной тусовкой, где можно блистать красноречием, острить, производить на девушек впечатление" [Тупикина].

В процессе совместного приготовления нехитрых блюд (плов, борщ, салаты, шарлотка) участники тусовки испытывают острую потребность в проговаривании детских травм, даже Миша признается, что его мать - алкоголичка и ему вместе с братьями пришлось голодать в детстве. Миша пытается проявить в каждом из трех участников и соседе-алкоголике Аркадии, некогда солисте известной музыкальной группы, способность выйти из зоны комфорта. Квартира-студия в пьесе может восприниматься как символическое пространство, совмещающее жилье, кабинет психолога, спальню и, собственно, кухню. В процессе приготовления блюда каждым из участников (этому посвящена отдельная сцена) рассказывается история травматических переживаний в детстве. Квартира-студия Михаила как пространство, предназначенное для единения людей во время совместного приготовления еды, становится эпицентром конфликтов, претензий друг к другу. Выход из зоны мнимого комфорта в процессе проговаривания травматической истории (в основном, из-за нелюбви матери) оборачивается 
для каждого из участников еще большей травмой. Так, недолюбленная мамой-директором Ольга осознает, что случайная близость с Михаилом произошла вовсе не из-за интереса к ней, а потому, что ему некомфортно было остаться наедине со своими мыслями. Кореец Слава, которого все дразнят «узкоглазым дрищом», был спровоцирован Мишей на акцию протеста. Ему не позволили готовить привычное для жителей современного русского города блюдо (салат из куриной грудки), а предложили нарезать салаты из всего, что есть в холодильнике. В результате всплеска некоординированных эмоций, он попытался перенести не свойственное ему состояние завоевателя и разрушителя на отношения с окружающими. Проявив напор в сексуальных отношениях с малознакомой девушкой, Слава понял, что он ей не нужен, и его самооценка еще более понизилась. Пространство квартиры-студии оказалось проникаемым из-за того, что в нее постоянно заходит сосед Аркадий, в прошлом музыкант рок-группы, а ныне опустившийся алкоголик. Он также становится жертвой психологических экспериментов Михаила, который предлагает ему продавать дешевые вещи в электричке в дорогом элегантном костюме. В результате Аркадий возвращается с побитым лицом: пассажиры электрички восприняли его внешний вид, не соответствующий роли убогого продавца мелочей, как вызов. Более того, квартира Михаила не вызывает ни у кого из персонажей чувство защищенности. В этой квартире-студии все ощущают свою беззащитность. В момент осознания того, что участники тусовки утратили чувство опоры в жизни, Лиза стучит в стенку и этим приглашает соседа к общению, видимо, с целью гармонизации отношений на кухне, где уже не до приготовления пищи.

Аркадий. А что это у вас едой не пахнет сегодня?

Миша. Оля, не драматизируй.

Оля. Не, ну долго мы будем притворяться, что все в порядке? Все в полной жопе, Миша. И это все видят. ${ }^{7}$

Таким образом, кулинарная тусовка из формата личностного тренинга, в котором (по замыслу тренера Миши) каждый сможет раскрыть нереализованные качества характера, превращается в способ выявить наиболее уязвимое место каждого (включая тренера) и ударить по нему как можно больнее. Но затем, как оказывается, от сугубо тусовочных участники кружка переходят к осознанию бытийных проблем. Локус квартиры-студии, в которой разворачиваются все

7 Ю. Тупикина, Кулинарный кружок, Театральная библиотека Сергея Ефимова, www.theatre-library.ru 
коллизии, играет, таким образом, миромоделирующую и психомоделирующую роль в поэтике пьесы. В процессе тусовки герои разочаровываются в возможностях и эффективности своей жизненной позиции. Например, Лиза отказывается от защитной маски-прикрытия, перестав выдавать себя за лесбиянку. Приготовление ею любимого десерта-шарлотки в финальной сцене пьесы можно рассматривать как жест определенного доверия миру, в том числе, миру мужчин и Михаилу.

Все персонажи пьесы приходят к переосмыслению своей настоящей жизненной ситуации. В сознании Михаила вообще совершается внутренний криз: он испытывает стресс, осознав, что в результате детских травм (невнимания к нему матери-алкоголички, голодания, жизни в интернате для сирот после ее смерти) он так и не научился любить. Тусовка вызвала у всех персонажей потребность переоценки ценностей. Можно отметить, что она не сплотила, а, скорее, отдалила их друг от друга. Более того, в финале пьесы разрушается тусовочное общение героев как некой самодостаточной, закрытой для проникновения внешнего мира символической общности. Само пространство квартиры-студии, в которой отсутствуют перегородки, передает идею отсутствия внутренней изоляции участников от окружающего мира. Отсутствие запрета на вход посторонних лиц и утрата интереса к общей для всех участников теме свидетельствует о том, что тусовка утратила характер коммуникативного сообщества.

Таким образом место тусовки приобретает характер пространственного осуществления целей общения, задач маркировки своего и чужого мира, процессов осознания героями себя. Сама локация тусовки воспроизводит символическое представление о смысле общения внутри некого сообщества молодых людей, входящих в стадию полового созревания. Последнее проявляется особенно выразительно в пьесах для подростков и о подростках. Так, в пьесе Л. Духаниной «Тусовка ранним вечером, молодежная новелла в 2-х действиях» (2008) подростки сознательно используют тусовку в квартире одной из девочек (Алисы) для выяснения отношений, проявления ревности, мести, а, заодно, и завязывания новых отношений. Пространство частной жизни в квартире позволяет героям соотнести свои взгляды с некой этической нормой, сложившейся еще задолго до их появления. Хотя хозяйка квартиры несколько раз повторяет, что родители уехали на похороны дедушки, эта ситуация не вызывает у ее одноклассников интереса. Более того, ограниченное пространство общения способствует выплеску агрессии: одна из девочек мстит бывшему парню (Денису), заставив его 
унизиться: стать на колени. Оказывается, что подросткам трудно приспособиться к ролевым моделям поведения в обществе. Например, один из друзей Дениса, которого жестоким образом «подставили» в спортзале, подкинув ему в шкафчик для одежды наркотики, отказывается это подтвердить публично. Он на горьком опыте перевода в другую школу узнал, чем может быть чревата помощь друзьям. В процессе тусовки осознается понятие нормы поведения в социуме. Проявление так называемой «антинормы» создает условную границу между подростками, создающую коммуникативный барьер между «своим» и «чужим» мирами.

Интересно, что в некоторых пьесах для подростков пространство комнаты, в которой происходит тусовка, сопоставляется с открытым пространством улицы. В пьесе И. Васьковской и Д. Уткиной «Дар моей невинности» (2008) действие происходит в квартире, причем, во всех ее комнатах, даже в ванной, где одна из участниц, Настя, эпатажно демонстрирует (мнимую) раскованность и осведомленность в интимном общении, а затем вдохновенно читает рэп. В тусовочном общении проявляется агрессия подростков по отношению друг к другу и себе. Игра в античных богов, ставшая темой тусовки, оказывается способом раскрепощения и отчуждения от своего привычного образа жизни, поведения. Примеряя на себя маску богемного писателя, старшеклассница Юлия проводит в своей квартире вечеринку-оргию под названием «Люди и Боги». Сквозь маску эпатажной бравады, грубой обсценной лексики, обнаруживается детская беззащитность героев, страх перед будущим, перед сексуальным опытом. Демонстративная имитация героями сексуальной оргии ( символически воспроизводится модель поведения взрослых) может рассматриваться как стремление маркировать определенные коды поведения «взрослых» тусовок. При этом открыто проявляется пролонгированное сохранение детского самосознания всеми персонажами и, прежде всего, демонстрирующей эпатажную раскованность Юлией ${ }^{8}$. В их высказываниях проявляется детская травма из-за непонятости или ненужности в семье. Кризис одиночества особенно отчетливо осознается Настей во время ожидания автобуса (в открытом пространстве улицы). Возможность наблюдать течение взрослой жизни обращает ее взгляд на себя, на свое поведение. В процессе самоанализа она сообщает Полицейскому о том, что ее мать пять лет

8 Отметим, что в работах Т. Щепанской трансляция детского поведения рассматривается как один из важнейших кодов передачи вневременности тусовочного сообщества. См. Т. Щепанская, Система: тексты и традиции субъкультуры, М., 2004, c. $43-47$. 
мечтала о ребенке и ждала ее появления на свет. Тем самым героиня подчеркивает собственную значимость. Проявление разнообразных, зачастую противоположных (от ненависти к матери до потребности ее защитить) эмоций в пьесе передает несформированную жизненную позицию героев. Не случайно Юлия постоянно выражает стремление приобрести жизненный опыт. В ее речи слово «опыт» воспринимается как имитация мира взрослых: так, она хочет узнать, что такое «просто умирать» для жизненного опыта. Кризис взросления зачастую является темой пьес современных драматургов, предназначенных в равной степени для подростков и взрослых. Местом действия в них нередко становится часть дома, обособленная от постоянного проживания семьи. Так, чердак для компании подростков из одноименной пьесы Л. Духаниной (Чердак, 2014) служит тем условным местом, где они могут быть собой и принадлежать себе, независимо от регламентирующих их поведение взрослых. Действие разворачивается в пространстве уединенного чердака, куда сбегает героиня (несовершеннолетняя Женя), не найдя понимания с матерью и поддержки у отца, который живет с другой семьей.

На чердаке она встречается с тремя подростками, для которых он стал привычным местом тусовки. Для матери Жени и родителей Ильи чердак - опасное место, уединение в пространстве которого может принести их детям вред. Для убежавшей от матери Жени, которую ждет комиссия по делам несовершеннолетних, чердачное пространство связано с памятью утраченного дома, в котором прошло ее детство и (уже с новой семьей) остался жить ее отец. С этим домом, как и с отцом, утрачиваются связи, только чердак еще может стать для нее убежищем, ограждающим от нежелательных контактов с миром. Новые друзья-подростки (называющие себя бандой), оказываются вполне интеллигентными, разумными молодыми людьми. Они, вместе с Женей, осознают некоторые трудности перехода во взрослую жизнь, в том числе, потребность компромисса. Пространство чердака кажется подросткам идеальным местом для изоляции от мира взрослых, сохранения своего внутреннего мира и определенных норм поведения до того времени, пока их не закрывает там на ключ сосед снизу, который при этом говорит, что на несколько дней уезжает в командировку. Эта ситуация способствует осознанию подростками истинных и иллюзорных ценностей, а также помогает четырнадцатилетней Жене повзрослеть и понять, как и с кем ей жить дальше. Тусовка подростков представлена в пьесе как некий механизм социальной адаптации, способ приобретения жизненного опыта (каждый по-своему, например, оценивает то, 
что Илья за ограбление ларька получил условный срок). Во время общения проявляются увлечения подростков, характерные для тусовочных сообществ (Светка по любому поводу читает рэп и вовлекает в это остальных, подростки вместе планируют акцию протеста). Действие пьесы представляет собой две отдельные сцены: общения подростков (тусовка как процесс изолированной от мира коммуникации) и конфликтной ситуации недоразумения с проживающим под чердаком парнем-дальнобойщиком Толиком. Форма драматических картин создает иллюзию статичности действия, отсутствия одного центрального конфликта, вместо которого представлены случайные столкновения между героями, вызванные непониманием. Появление на чердаке соседа Толика изменяет и разрушает привычный характер тусовки. То, что он закрывает чердак на ключ, принципиально изменяет характер общения героев и их отношение к себе... Маркером неожиданного «вламывания» законов жизни взрослых в тусовочное пространство подростков является их оценка случайного обнаружения одним из них пистолета Толика. В сознании подростков начинают действовать стереотипы, усвоенные ими в связи с потреблением ими продукции масс-медиа. Ожидание мести со стороны Толика, принимаемого ими за уголовника, изменяет их психологическое состояние. Они чувствуют себя заложниками сложившейся ситуации, чему способствует принудительная герметизация чердачного пространства, утратившего при этом свойства защищенности от мира взрослых. Невозможность выйти усиливает их представления о собственной уязвимости. Одна из девушек, играющая в тусовочном сообществе роль поэта-сказителя (Светка) воспроизводит медийную модель нападения на прохожего. Ее текст является сообщением о том, что двое ребят из тусовки ограбили на улице случайного прохожего. В форме рэпа героиня излагает историю того, как один из них(Илья) получила условный срок. Финальная сцена демонстрирует разрушение тусовочного пространства в связи с проникновением людей из «взрослого мира». Причем неопределенному в его поведении Толику противопоставлена Полина, взявшая на себя функцию примирения Жени с матерью.

Как уже отмечалось, дом в сознании героев уже не вызывает стойкое чувство защищенности как это было присуще человеку традиционной культуры [Башляр 2014, 58 $]^{9}$. Даже чердак, убежище для „без-

9 В работе Гастона Башляра Поэтика пространства отмечено, что дом в воображении человека пробуждает в нас сознание вертикальности, центральности, это важнейший интегрирующий принцип для идей,воспоминаний и грез. Г. Башляр, Поэтика пространства, Москва 2014, с. 58. 
мятежного одиночества" [Башляр 2014, 69], утрачивает свои функции приюта для одинокого мечтателя. Можно сказать, что состояние оторванности от привычной среды дома необратимо вызывает необходимость вернуться в нее. Герои пьесы Чердак только временно обретают иллюзию свободы выбора в рамках молодежной тусовки, во время которой усиливается чувство одиночества, ненужности, что и побуждает вернуться к привычному образу жизни, существующему в сознании как топос дома.

В пьесах на тему молодежной тусовки, как правило, нет главных героев, с внутренней динамикой сознания которых было бы связано драматическое действие. Зачастую сама тусовка (как социальный формат, институция общения) динамизирует процессы личностного сознания группы персонажей или одного из них. Нередко эти процессы осуществляются во взаимодействии всех (или многих) участников тусовки. Выделение какого-то персонажа из группы тусующихся как правило свидетельствует о назревшей потребности изменения его самосознания.

Думаю, что тусовочное сообщество можно рассматривать в тексте пьесы как самоорганизующийся социальный механизм (со своими законами, иерархиями, институтом власти, аутсайдерами и фаворитами).

Тусовка изменяет сознание, самооценку героев, но при этом изменяется и сама. Речь идет о том, что молодежная тусовка в пьесах репрезентируется как приватное пространство, то есть, используя выражение Шарон Зукин, пространство, транслирующее частные интересы. При этом приватное пространство в большинстве пьес представлено как культурная среда, в которой возникают, множатся и трансформируются символы. Кроме общественного и приватного пространства в пьесах часто обнаруживается и пространство не-мест или симулякров (как обозначил это явление Марк Оже).

Так, в пьесе санкт-петербургского автора Игоря Шприца Мерcu (2010) действие происходит в публичном пространстве улицы, подземного перехода, в пространстве квартиры и в похожем на клуб, не функционирующем по назначению, бомбоубежище. В нем собираются и, собственно, живут представители молодежной субкультуры: проститутки, жиголо, музыканты, сестры-танцовщицы, а также диск - жокей, главный организатор и хозяин тусовки (местный гуру) по имени Антон. Их тусовочное общение определяет символика андеграундного самосознания. В пространство не-места случайно попадает скрывающийся от полиции студент - юрист Матвей, поведение которого во многом и определяется характером этой тусовки. Он вступает в слу- 
чайную связь с двумя девушками, ведущими свободный образ жизни. Впрочем, он не утрачивает привычку говорить и действовать в соответствии с правилами, регламентирующими поведение в общественных местах. Не случайно по поводу любой ситуации он тут же зачитывает статью уголовного кодекса, который знает наизусть. Собственно, действие пьесы позволяет представить, как герои переходят от коллективного (общественного) восприятия пространства и событий, происходящих в нем, к приватному и, наоборот, и как в одном восприятии «прорастает» другое. Так, одна из героинь пьесы, нуждающаяся в социальной защищенности, а, вместе с тем, в яркой, полной событиями жизни, девушка Людмила с придуманным ею же именем Мерси (от Мерседес - Божья милость) чудом( в результате шантажа отца одной из представительниц тусовки) получает предмет своих детских грез - белый мерседес. От реалий действительности (пьющей матери) она спасается в пространстве бомбоубежища, преобразованного для свободной жизни, однако сохраняет потребность в настоящей любви. В ее сознании границы публичного и приватного крайне размыты, она лучше всего себя чувствует (и остается собой) в салоне своего мерседеса. Это единственная возможность сохранить возникшую еще в детские годы идентификацию с актрисой, которая снималась в кино, разъезжая на белом мерседесе. Разочаровавшись в своей мечте о настоящей любви, Мэрси навсегда, как и большинство других героев, покидает бомбоубежище и тусовку. Она пытается убежать от своего чувства к Матвею. Героиня едет на большой скорости, убегая от себя, представляемой в образе другой, взлетающей к солнцу. Ее детская мечта превращается в трагическую реальность катастрофы.

Ремарка: Желтое солние слепит Мерси, Она закрывает глаза, Дикий скрежет тормозов, Мерси встает с кресла и идет - летит навстречу солниу ...Натыкаясь точно на стеклянную стену, по которой сползает на дорогу ... и застывает в позе сломанной кукль [Шприц].

После ее смерти Матвей окончательно покидает пространство тусовки, он пытается разговаривать с Богом в подземном переходе, там, где отсутствуют признаки какой-либо частной жизни, а окружающим (кроме Мента) нет до него дела. Безличное пространство подземного перехода, соотносимое с пространством бомбоубежища, где собирается тусовка, дает временную иллюзию свободы, но, вместе с тем, лишает человека опыта освоенного пространства, в котором можно оставаться собой. Думаю, что в этой пьесе И. Шприца представлены процессы пробуждения личностного (само)сознания представителей разных 
слоев молодежи, которые сближаются и взаимовлияют друг на друга во время тусовки. Собственно, тусовка предстает как живой организим, со своими противоречиями, казусами, болезнями. Она, с одной стороны, социализирована, а, с другой, в ней каждый остается один на один с собой. Видимо, поэтому бомбоубежище остается временным пристанищем, которое покидают герои, пережив кризис личностного самосознания.

В последнее время интерес исследователей притягивают пьесы, в которых представлена виртуальная тусовка с магическим эффектом перезагрузки сознания героев и реципиента. Продуцирование гиперреальности в соцсетях, порождающей симулякры, приобретает в пьесах фантасмагорически угрожающий характер: подобно мифологическому монстру медиареальность готова поглотить ту квазиреальность, которую она же и произвела. В пьесах Наталии Блок Фото monлес (2015) и Игоря Витренко Кого я нашел в соисети (2015) тусовка подростков напоминает игру, содержащую магические ритуальные жесты, символы, реакции. При этом стирается грань между реальным миром героев и виртуальными фантомами (фейками) или порожденным гиперреальностью фотоуниверсумом (используя выражение Вилема Флюссера). В пьесе Натальи Блок выложенные подростками в интернет и пересылаемые с оценками (лайками), комментариями фотографии становятся средством создания некой гиперреальности 10 или медиареальности. Диалог между двумя симпатизирующими друг другу подростками (Кирой и Артемом) осуществляется с помощью пересылаемых ими фотографий. Они тут же становятся достоянием медиареальности и подкрепляются в ответ ритуальными жестами, содержащими реакции на послание, запечатленное в образах. В таких жестах (например, в реакциях пользователей фейсбука на появляющиеся изображения) проявилась магическая модель поведения: пользователи (одноклассники Киры и Артема) находятся во власти «фотоуниверсума»: познают мир, переживают, оценивают поступки, исходя из функций фотографии.

Жест Артема (просьба прислать фотографию Киры топлесс) сопровождается неожиданной реакцией: присланное фото груди способствует созданию новой гиперреальности. После того, как оно стало тиражироваться, оцениваться (в сети пользователей возникла по-

10 Речь идет о моделировании средствами СМИ некой альтернативной реальности, искусственно созданной в данном случае в результате трансляции фотографий в интернете и их обсуждения. В дальнейшем используем понятие в этом же значении. 
лемика, принадлежит ли эта грудь Кире или нет?..), медиареальность «создала» неожиданное последствие: в интернете распространилась весть о том, что отчаявшаяся Кира покончила жизнь самоубийством. Гиперреальность спровоцировала мифологизированное состояние «побега в никуда» как некого симулякра. Так как одноклассники Киры не догадывались, что информация о суициде оказалась ложным медиальным продуктом, новость мгновенно распространилась в интернете.

Медиареальность готова была поглотить ту квазиреальность, которую она сама же и породила. Как отмечено в ремарке, Артема фотографиями девушек топлесс. Можно думать, что зло, порожденное Артемом в интернете, приобрело характер стихийного бедствия. «В социальных сетях проходит флешмоб. Все девушки выкладывают фото топлес на свои странички и пишут «Угадай чья?», «У всех есть грудь», «Что, чувак, груди не видел?», «На, позырь на сиськи». Все ставят хештег «Кира, прости!». Артем обновляет ленту, и вся она превращается в сплошные фотографии груди...» [Блок] ${ }^{11}$ В поэтике высказывания распознаются иллокутивные жесты, обращенные к реципиенту. Нарративизируется способ обращения к читателю/зрителю. Собственно, в пьесе зафиксировано ощущение того, что все: и юные герои, которым адресована пьеса, и читатели/зрители - являются частью медиареальности. Об этом красноречиво свидетельствует следующая ремарка: «Школьный коридор. Двери в кабинеты. Школьники стоят двумя группами - девочки отдельно, мальчики отдельно. Они друг друга не видят. В руках у них смартфоны. У Артема планшет.» [Блок]12. В пьесе Натальи Блок достигается эффект исключения субъекта (в данном случае, девушки Киры) из референтного поля продуцируемой посредством медиа квазиреальности. Можно предположить, что в финале пьесы героиня обретает собственную идентичность путем отстранения от фотоуниверсума, пусть и в ситуации порожденной медиареальностью иллюзии суицида.

Представленная в виртуальной реальности тусовка обладает к тому же эффектом программирующей магии. Скажем, сюжет пьесы И. Витренко напоминает в чем-то черты современных фэнтези (разоблачается стремление порожденных интернет тусовкой образов захватить власть) и с помощью случайно найденного на сайте магическо-

11 Н. Блок, Фото топлес / theatre-library.ru/authors/b/blok Наталыа (Дата обращения: 20.05.19).

12 Н. Блок Фото топлес 
го заклинания удается справиться с виртуальными монстрами, один из которых уже поселился в теле и сознании одной из учениц его школы). Поведение фейков в пьесе репрезентирует реалии современных ритуалов социальной коммуникации (они сохраняют правила дистанции в общении, ведут себя как наставники в случае «проколов» в поведении подростков).

В обеих пьесах действие характеризуется иммерсивностью (погруженностью) в виртуальную гиперреальность, способностью вовлечь читателя, зрителя в пространство коллективного виртуального, в связи с чем обнаруживается возможность для убегания от себя и действительности, а также удовольствие от прикосновения к магическим ритуалам, тайнам Бытия.

Таким образом, в результате проведенного анализа видим, что тусовка организует пространство действия структурно, формирует его, придает ему значимость и значение феномена личностного и коллективного самосознания. Вследствие символизации и магической ритуализации реального места и виртуального пространства тусовки обнаруживаются процессы самоидентификации героев, которые и составляют основу действия в проанализированных пьесах. Осуществляется транспозиция приватного и общественного пространства. В связи процессы, происходящие в сфере самосознания героя чаще всего представлены в гиперреальном плане. Личностные коллизии, обусловленные ростом самосознания взрослеющего подростка( в пьесах для подростков, прежде всего) придают месту действия символический характер пространства бытия. Перенос действия за границу дома (квартиры) позволяет представить несколько планов в формирующемся сознании подростка, в том числе, плана прошлого, настоящего и будущего. Процессы самоидентификации героев побуждают их покинуть пространство тусовочных сообществ, будь-то квартира-студия, чердак или бомбоубежище. Любое замкнутое тусовочное пространство усиливает внутренние конфликты героев-подростков с собой. Виртуальное пространство гиперреальности создает фантомы не-мест, в которых тусовка приобретает черты медиамонстра, поглощающего личностный опыт юных героев.

\section{Литература}

Bašlâr G., 2014, Poètika prostranstva, Moskwa. [Башляр Г., 2014, Поэтика пространства, Москва.] 
Duhanina L., Skamejka $M+K$, Teatral'naâ biblioteka Sergeâ Efimova, www. theatre library.ru [Духанина Л., Скамейка $M+K$, Театральная библиотека Сергея Ефимова, www.theatre library.ru.]

Lebedeva E., 2016, Transformaciâ publičnogo prostranstva postsovetskih gorodov, „Sociologiâ", № 4, s. 108. [Лебедева Е., 2016, Трансформаиия публичного пространства постсоветских городов, „Социология”, № 4, с. 108.]

Lefevr A., 2015, Proizvodstvo prostranstva [Лефевр А., 2015, Производство пространства].

Lur'e M., Kuleva M., Fil'truj diskurs: kak živet nетербургская тусовка, [online], https://www.svoboda.org [Лурье М., Кулева М., Фильтруй дискурс: как живет петербургская тусовка, [online], https://www.svoboda.org].

Makhanina N., Nasrutdinova L., 2017, Spetsifika khudozhestvennogo prostranstva dramaturgii Ksenii Dragunskoy dlya podrostkov [v] Sovremennaya rossiyskaya i yevropeyskaya drama i teatr, Kazan'. [Н. Маханина, Л. Насрутдинова, Спеиифика художественного пространства в драматургии Ксении Драгунской для подростков в Современная российская и европейская драма и театр, Казань].

Miziano V., 2002, „Tusovka” kak sociokul'turnyj fenomen, [v] Hudožestvennâ̂ kul'tura XX veka, Sbornik statej, Moskwa. [Мизиано B., 2002, „,Tусовка” как соииокультурный феномен, [в] Художественная культура ХХ века, Сборник статей, Москва].

Neformal'nye molodežnye soobŝsestva Sankt-Peterburga: teoriâ, praktiki, metody profilaktiki èkstremizma, 2008, red. A. Kozlova, Sankt-Peterburg. [Heфopмальные молодежные сообщества Санкт-Петербурга: теория, практики, методь профилактики экстремизма, 2008, ред. А. Козлова, Санкт-Петербург].

Špric I., „Mersi”, pečal'naâ istoriâ, Teatral'naâ biblioteka Sergeâ Efimova, [online], www.theatre-library.ru [Шприц И., „Мерси”, печальная история, Театральная библиотека Сергея Ефимова, [online], www.theatre-library.ru]

Tupikina Û., Kulinarnyj kružok, Teatral'naâ Biblioteka Sergeâ Efremova, [online], www.theatre-library.ru [Тупикина Ю., Кулинарный кружок, Театральная библиотека Сергея Ефремова, [online], www.theatre-library.ru].

Krajewska A., 2009, Narracyjne $i$ dramatyczne ujęcia przestrzeni $w$ dramacie XX wieku, [w] Przestrzenie we wsplczesnym teatrze i dramacie, Kraków.

\title{
LOCUS OF YOUTH PARTY IN MODERN DRAMA WRITTEN IN RUSSIAN LANGUAGE
}

\author{
ABSTRACT
}

The article analyzes how the nature of space (or place) representation in modern drama of Russian-speaking authors (L. Dukhanina, I. Vaskovskaya and D. Utkina, I. Shpritsa, Y. Tupikina) contributes to the symbolization of the pro- 
cesses of self-awareness and self-identification among characters. There are patterns of transformation of private and public places into a type of lifestyle that can be traced, as well as the behavior of a certain sociocultural institution - youth party. In the plays, the party is presented as a self-organizing phenomenon in which a metatheatrical scenario of the behavior of its participants is realized, and personal and collective interests create a certain model of socialization among youth groups. Real and virtual space in plays has the properties of immersive reload for the reader/viewer.

Key words: youth party, self-identification, lifestyle, space, place 